\title{
1. Introduction: perspectives and positions of major countries
}

\section{Jehoon Park}

Northeast Asian regionalism has been a keen issue since the 1997 Asian financial crisis, which confirms the argument that only crises stimulate regionalism. In contrast with the fact that Free Trade Agreements (FTAs) and security cooperation have not yet produced any real output, financial regionalism has been relatively successful in East Asia due to the lessons drawn from the Asian financial crisis. The North Korean nuclear issue could be the second source of momentum for regionalism in Northeast Asia. The Six Party Talks may become a regional forum which could be developed into a multilateral security cooperation organization in the region.

It took some time for the intellectual community in Northeast Asia or East Asia to understand the implications and the meanings of the Asian financial crisis. It was only in 2001 that the intellectuals in the region began to organize their activities in order to suggest policy options for the long-term goal of establishing a regional integration body like the 'Northeast Asian Community'. Among the prominent academic NGOs aiming at an international movement for Northeast Asian regionalism is NAIS Korea (Northeast Asia Intellectuals' Solidarity Korea) which was established in 2001 as a result of the initiative of South Korean intellectuals.

This chapter summarizes and evaluates various arguments suggested by papers presented at the five consecutive NAIS international conferences, including chapters from the monograph published by NAIS in 2004 under the title of Toward the Northeast Asian Community: Dreams and Realities of Asian Regional Integration (in Korean). Perspectives and positions of major member countries, that is, China, Japan and South Korea, are introduced and summarized. A political economy approach is adopted so that issues of politics and security as well as economy can be analyzed jointly. 


\section{PERSPECTIVES AND POSITIONS OF CHINA}

If we make an overall estimation based on the three-dimensional framework of state (politics and government), market (economy) and society (civil society and NGOs), ${ }^{1}$ in terms of fields and sectors, it may be noted that China adopts more realistic approaches and emphasizes the roles of state and government in regional integration, which is understandable when considering that China is still a statist country controlled by a strong Communist party. As Chinese society still has a very weak voice in terms of Western standards, therefore, it may be natural that China seems to prioritize issues of security and economy over those of society in terms of fields. Although the thrust is put on the orientation of East Asia rather than Northeast Asia, more active interests in regional integration have been displayed than initially expected.

\section{Politics and Security}

Vice-president of Fudan University of China, Mingyang Xue (2001) emphasizes the importance of Northeast Asian security cooperation for the construction of the Northeast Asian Community. While he points out the differences between Northeast Asia and Europe, he emphasizes the importance of economic integration for the formation of a security cooperation body. He already claims that this can become the basis for a Northeast Asian security cooperation body if the Six Party Talks concerning the solution of the Korean Peninsula problem succeed.

Liu (2007) analyzes the somewhat positive roles of China in Northeast Asian Security Regionalism (NEASR). He refers to NEASR as 'intensifying processes of cooperation and/or cooperative ideas undergoing mainly among these states: two Koreas, Japan, China, Russia and the United States'. According to his argument, China changed its view on the US military role in Northeast Asia, acknowledging that US interests in Northeast Asia are understandable and do not necessarily conflict with those of China. Emphasizing the uniqueness of Northeast Asia as a region and its historical and present context in which the regionalism unfolds, makes the process both encouraging and stunted; Liu concludes, however, that 'economic regionalism in Northeast Asia may not lead naturally to the realization of security regionalism in the short run' (Chapter 3 of this volume).

\section{Economy}

China wants to use the Beijing Olympics and the Shanghai World Trade Expos as opportunities for accelerating China's economic opening in 
relation to the global economy. It can be said that China is pursuing a socalled 'two-track strategy' in international economic cooperation. On the one hand, by participating actively in the globalization trend under the WTO system, China is trying to upgrade its institutions to international levels by integrating its economy into the world economy. On the other hand, China is pursuing a strategy of taking initiatives in East Asian regional integration with the purpose of increasing the role of Chinese economy as a regional center.

Jingyi Ye (2005) suggests a roundabout way via three parallel 'ASEAN $10+1$ ' structures to achieve the long-run goal of an East Asian Free Trade Area. According to her analysis, China is pursuing a two-track approach, where it is actively involved in and is promoting the arrangements of regional trade liberalization in East Asia, while pursuing multilateral trade liberalization through the WTO mechanism at the same time.

It may be interesting to note that in 2001 there was already an argument emphasizing the need to pursue in advance the FTA between Korea and China for the success of the FTA of Korea, China and Japan (Angang $\mathrm{Hu}$, 2001). Emphasizing Japanese roles in Northeast Asian cooperation, Jianren Lu (2003) claims that the appearance of 'a New Japan' is a central element for regional cooperation in order for Japan to find an identity in East Asia and to learn historical lessons from the past with a regional perspective along with a global one. He, at the same time, emphasizes American roles in Northeast Asia and asserts that the US should be used as 'public resources' of Northeast Asia, and should not be seen as an obstacle.

There is an argument suggesting three approaches for Northeast Asian Free Trade Agreement (NAFTA). The first is to start the process after all three bilateral FTAs are finished, and then to do a trilateral FTA, which needs time since only the Korea-Japan FTA has started negotiations. The second is to launch an independent process for NAFTA immediately since the joint study group has already finished its study, while its difficulty lies in weak social and political support. The last is to start with a trade and investment facilitation agreement and a trilateral investment agreement in 2007 or 2008, which can set up the foundation for NAFTA in the future (Zhang, 2006).

\section{PERSPECTIVES AND POSITIONS OF JAPAN}

Japan adopts different approaches from other countries and emphasizes the role of civil society in regional integration, which is natural considering the fact that Japan is the most developed country in terms of maturity of 
civil society in Northeast Asia. In terms of fields, therefore, it seems that relatively high priorities are society and culture. Initially Japan was actively in favor of concluding an FTA with Korea, but recently there has been a great deal of stalemate.

The late LSE professor, Morishima (1999) suggested a creative idea for Northeast Asian regional integration: the Japanese prefecture Okinawa should be independent from Japan to become the capital of the Northeast Asian Community, and China should be included as six blocs, the Korean Peninsula and Japan each as two blocs and Taiwan as one bloc so that the Community would be a 'Construction Community' rather than a 'Market Community'.

\section{Politics and Security}

A liberal intellectual and well-known internationalist in Japan, Yoshikazu Sakamoto (2001) insisted that to strengthen regional cooperation with a view to building a consolidated Northeast Asian community, it is imperative to transcend, at least intellectually, the traditional framework of the sovereign state system in the following four respects.

First, one must transcend the negative historical legacy of the region in terms of the imperialist war of aggression and colonial rule perpetrated by Japan, because the East Asian people's distrust of Japan and Japan's failure, or even unwillingness, to mitigate the distrust through a sincere apology for its historical wrongdoings clearly constitute the main obstacles to the enhancement of regional cooperation.

Second, to counter the trend toward aggravating global inequality and inequity, it is necessary to promote democratization at home based on the empowerment of civil society in each country, and to advance transnational democratization based on the regional and global solidarity of civil societies.

Third, the regional community of the intellectuals should retain autonomy from governments and corporations. The possibility and need of cooperation between them are not ruled out, but a degree of distancetaking is indispensable.

Fourth, there are two ways to transcend the framework of the sovereign state system. One is to transcend the national sovereignty at the top of the state to build a supranational world and/or regional organization. Strengthening the United Nations and the European Union is a case in point. The other is to transcend the national boundary at the bottom of the state in order to build a transnational civil society like a multitude of transnational NGOs. ${ }^{2}$ 


\section{Economy}

Motoshige Itoh (2006) emphasizes several factors blocking the realization of an FTA in this region. One of them is the chilly political relations between Japan and the other two countries, mainly due to the Yasukuni shrine issue. The lack of a summit meeting among the three made it difficult to have serious talks to initiate any kind of economic cooperation in this region. Second, there are needs to transform ASEAN+1+1+1 where each of the three countries has an FTA arrangement with ASEAN, to ASEAN+3.

In addition to political and emotional obstacles, Kimura and Ando (2006) discuss three symbolic obstacles to FTA negotiations: agriculture in Japan, the manufacturing sector in Korea, and the business environment in China. 'Agricultural protection in Japan is one of the most notorious examples of trade protection in the world', although shares of agriculturerelated imports in total bilateral imports, regardless of whether with tariffs or not, are only 6 per cent with Korea and 9 per cent with China in 2005, which indicates that 'it should not be a big deal for the whole economy of Japan even if the agricultural imports from Korea and China were liberalized' (Chapter 6 of this volume).

Criticizing the Japanese government's official position favoring an ASEAN+6 approach, Makoto Taniguchi (2007) proposes to start by establishing an 'East Asian Economic Community' first, at the level of ASEAN+3, developed from the present ASEAN+1, because the cooperation between Japan, Korea and China is vital, as the total Gross National Income (GNI) of these three major economic players in East Asia is nine times as great as that of the ASEAN 10. He urges Japan to make efforts to conclude the delayed bilateral negotiations with Korea as soon as possible. He also calls for a Northeast Asian Environmental Cooperation Organization as well as a joint energy development and oil reserve program among Japan, Korea and China, and technological cooperation to increase agricultural production and to secure the food supply in Northeast Asia. ${ }^{3}$

\section{PERSPECTIVES AND POSITIONS OF SOUTH KOREA}

South Korea seems to be the most active country in regional integration among the regional countries, although the concrete results have not yet been seen. At the intellectuals' level, it is emphasized that the harmony of the roles of state, market and civil society is crucial for the realization of 
regional integration. It is regarded as inevitable that Korea gives high priority to the solution of short-term security problems such as North Korea's nuclear issue as well as mid- and long-term economic problems such as the construction of the 'Northeast Asian hub' country. It may be noted that the current Korean government was initially interested in the construction of Korea as the Northeast Asian hub country, while intellectuals and the private sector think that it is wiser to emphasize the mediator role of regional integration such as a Northeast Asian Community, especially toward the outside world. Roh's government emphasized the role of a 'balancer' which caused controversy regarding the true implications and intentions, while NAIS emphasizes more cautious and modest roles of a 'mediator' or a 'coordinator'.

With regard to the future of China, the former vice premier of the South Korean government, Soon Cho (2003) raises the question, 'Is China going to go democratic in the future?' His answer is that 'it appears that [the] answer is yes, but in a Chinese way'. He concludes that 'China is at its threshold of a civil society, but the country won't follow the George Washington model, and it will do its own thing.'

One of the well-known liberal writers in South Korea, Won-shik Choi (2004) suggests a 'trichotomy theory of the world'. It is a trichotomy theory because the 'East Asia discourse' is looking for new ground from the US and the EU. And it is a trichotomy theory also because, although the Soviet Union has already collapsed, 'the 20th century's socialist experiment' is treated as an important object of evaluation together with American capitalism, and a third way is being sought. Choi's 'East Asia discourse' does not imply a hegemonic idea where East Asia should become a new center against the US and the USSR or the US and the EU. Because of this, it is sharply different from the famous ancient Chinese politician, Kongmyung's trichotomy. It is argued that it is an earnest message for peace; by overcoming the Korean Peninsula's division peacefully, Korea is looking for a new principle of forming a new world beyond statism and nationalism.

The late historian and the former president of Seoul National University, Byung-Ik Koh (2003) argued that 'we have a misconception that East Asia had a tradition that among the intellectuals of three countries, there have been active cultural exchanges. But in fact, the tradition has been lost since the 17 th century until recently. Therefore, we, intellectuals of the 21 st century, have a historical duty of revitalizing the tradition.'

Rozman (2004) recognizes South Korea's critical position in bringing China and Japan together in the triangular core of regionalism. It should be noted, however, that the domestic ideological split is becoming reinforced in South Korea. It is not at all easy to reach a national consensus 
about a critical agenda including regional integration. One of the factors making things worse is the ideological discord between the New Right vs. the New Left. As seen in the case of the Korea-Chile FTA, and more recently the Korea-US FTA, regional integration is a very conflictive issue and potentially quite explosive.

\section{Politics and Security}

It seems true that the construction of regional integration such as a Northeast Asian security cooperation body in the region is unrealistic in the near future because of the numerous barriers such as the American influence, the North Korean issue, and so on. But in the field of international political science, theoretical studies about the possibilities of constructing a cooperation body and regional integration in Northeast Asia have already proceeded, based on the spreading and application of the modern European experience. Recently, it is reaching a new turning point, as the discussions concerning Northeast Asian cooperation at the government level have been proceeding well along with the establishment of The Asia-Europe Meeting (ASEM) and the regularizing of summit meetings among the three countries.

Young Jong Choi (2007) argues that conventional theoretical approaches predict that regional integration in East Asia is a distant possibility, identifying four key conditions for the success of regional integration: functional demands, leadership, common exigencies or sharing of strategic interests, and common identity. It is concluded that Northeast Asia has failed to meet these conditions up to now, and the situation is likely to continue for quite a while. 'Northeast Asia may have to continue pursuing boring functional cooperation at all levels, for example, political, social, cultural, legal, economic, and so on' (Chapter 4 of this volume).

With regard to financial cooperation in East Asia, Jin-Young Kim (2007) asserts that 'financial cooperation of the APT is a new phenomenon which deserves more theoretically guided understanding and more researches based on major International Relations (IR) and International Political Economy (IPE) theories. Because it is still at the infant stage it may be somewhat risky to predict its future course. There may be more rocks and reefs that impede the progress of financial cooperation of APT.' (See Chapter 8 of this volume for the issues related to the financial cooperation in East Asia.)

\section{Economy}

Inkyo Cheong (2007) describes the details of the initial FTA roadmap of the South Korean government from the experiences of working for the 
government. It is known that 'initially, the possibility of a Korea-Japan FTA was higher than a Korea-China FTA or a C-J-K FTA. According to the 2003 Korean FTA roadmap, Japan, Singapore, EFTA, India and ASEAN were categorized as the candidate countries for concluding FTAs in the short term, while the US, China, the EU and South America (Mercosur) were categorized as the candidate countries for concluding FTAs in the mid and long term' (Chapter 5 of this volume).

A realistic policy suggestion is made by Hyungdo Ahn (2006) concerning a plausible channel towards a $\mathrm{C}-\mathrm{J}-\mathrm{K}$ FTA, which could be constructed through multiples of ASEAN+1's: ASEAN+Korea, ASEAN+Japan and ASEAN+China. He states that 'for the moment, however, CJK investment agreement as was announced recently by Economic Ministers from [the] three countries could be considered in order to provide a useful starting point for deepened economic cooperation between [the] three countries in the future' (Chapter 7 of this volume).

In conclusion it may be said that South Korea is the most active in Northeast Asian regional integration, whereas China and Japan still have negative perceptions of each other. Generally speaking, the level of functional integration in the economy is higher than the level of cooperation in politics and security. However, there is still a need to pursue institutional integration.

The chapters of this volume analyze the issues of Northeast Asian regionalism in more detail. Among them, Chapters 2, 3 and 4 focus on the political issues from the perspectives of the US, China and South Korea, although Chapter 4 tries to suggest more theoretical views from a general perspective. Chapters 5, 6, 7 and 8 analyze the economic issues focusing on the FTA and financial cooperation from the perspectives of South Korea and Japan. It is interesting that Chapter 9 alone touches on the European cases in the context of comparison with Northeast Asia. Chapter 10, the conclusion, tries to suggest models of regional integration in Northeast Asia, based on the summaries of the discussions from the previous NAIS conferences as well as from this volume.

\section{NOTES}

1. For the details, see models and theories of regional integration in Chapter 10, the conclusion of this volume.

2. Keynote speech at the 1st NAIS international conference 28 November 2001.

3. Keynote speech at the 5th NAIS international conference on 20 February 2007. 


\section{REFERENCES}

\section{In English}

Ahn, Hyungdo (2006), 'FTA policies of CJK and prospects of CJK FTA: Korean perspective', paper presented at the KIEP-NAEAK International Conference on Prospects for Regional FTA(s) in Northeast Asia in Seoul, Korea, 14 December 2006.

Cheong, Inkyo (2007), 'The progress of Korea's FTA policy in the context of Northeast Asian economic cooperation', paper prepared for the 5th International Conference, hosted by NAIS Korea, in Seoul, Korea, 20 February 2007.

Cho, Soon (2003), 'Asian pattern of development in the 21st Century - with special Reference to Rise of China', keynote speech, the Third International Conference Hosted by NAIS Korea, in Seoul, Korea, 24-5 October 2003.

Choi, Young Jong (2007), 'Northeast Asian regional integration - theories, current state, and future prospect', paper prepared for the 5th International Conference, hosted by NAIS Korea, in Seoul, Korea, 20 February 2007.

$\mathrm{Hu}$, Angang (2001), 'Free Trade Area in Northeast Asia: A Chinese perspective', paper prepared for the 1st International Conference, hosted by NAIS Korea, in Incheon, Korea, 28-29 November 2001.

Itoh, Motoshige (2006), 'FTA policies of Northeast Asian countries and possibilities of Northeast Asian FTA(s): Japanese perspective preliminary draft', paper presented at the KIEP-NAEAK International Conference, Prospects for Regional FTA (s) in Northeast Asia, 14 December 2006.

Kim, Jin-Young (2007), 'Is the financial cooperation in East Asia progressing?' paper prepared for the 5th International Conference, hosted by NAIS Korea, in Seoul, Korea, 20 February 2007.

Kimura, Fukunari and Mitsuyo Ando (2006), 'Obstacles and variables of Northeast Asian FTA(s): Economic obstacles', paper presented at the KIEPNAEAK International Conference, Prospects for Regional FTA $(s)$ in Northeast Asia, in Seoul, Korea, 14 December 2006.

Liu, Yongtao (2007), 'Northeast Asian security regionalism: a Chinese perspective', paper prepared for the 5 th International Conference, hosted by NAIS Korea, in Seoul, Korea, 20 February 2007.

Lu, Jianren (2003), 'Economic cooperation of Northeast Asia', paper presented at the international symposium organized by the Presidential Commission on Policy Planning.

Rozman, G. (2004), Northeast Asia's Stunted Regionalism, Cambridge: Cambridge University Press.

Sakamoto, Yoshikazu (2001), 'Building a Northeast Asian Intellectual Community: problems and prospects', paper prepared for the keynote speech at the 1st International Conference, hosted by NAIS Korea, in Incheon, Korea, 28-29 November 2001.

Taniguchi, Makoto (2007), 'East Asian Community: Japanese perspectives - the role of 3 Major Economic Players in Northeast Asia', paper prepared for the keynote speech at the 5 th International Conference, hosted by NAIS Korea, in Seoul, Korea, 20 February 2007.

Xue, Mingyang (2001), 'On establishing a security system of Northeast Asian Community', paper prepared for the keynote speech at the 1st International Conference, hosted by NAIS Korea, in Incheon, Korea, 28-29 November 2001. 
Ye, Jingyi (2005), 'East Asian economic integration and China's position', paper prepared for the International Conference, Building One Asia and Global Hub, in Seoul, Korea, 16-17 June 2005.

Zhang, Yunling (2006), 'Some thoughts on Northeast Asian FTA', paper presented at the KIEP-NAEAK International Conference, Prospects for Regional FTA $(s)$ in Northeast Asia, in Seoul, Korea, 14 December 2006.

\section{In Korean}

Choi, Won-shik (2004), " "East Asia discourse" as a "triangular theory", in NAIS Korea edition, Toward the Northeast Asian Community, Seoul: Donga Ilbo, pp. 9-24.

Koh, Byung-Ik (2003), 'On the history of intellectuals' exchange in East Asia', Keynote speech at the monthly seminar hosted by Northeast Asia Intellectuals' Solidarity Korea.

Morishima, Michio (1999), Why Japan Declines, Korean edition, KDI. 